\title{
THE EFFECT OF ECONOMIC OPPORTUNITIES, AVAILABILITY OF INFRASTRUCTURE, POSITIVE CULTURE, AND CAPITAL ACCUMULATION ON DEPTH / POVERTY GAP IN BALI PROVINCE, INDONESIA
}

\author{
Marhaeni A.A.I.N., Sudibia I Ketut, Yuliarmi Ni Nyoman \\ Faculty of Economic and Business, Udayana University, Denpasar, Indonesia \\ *E-mail: marhaeniagung@gmail.com
}

\begin{abstract}
Poverty Eradication is one of the programs of SDGs (Sustainable Development Goals) implemented in all countries that ratify the SDGs Program which begins in 2015. The SDGs program shows that poverty alleviation programs are one of the countries' concerns to be abolished. This condition reflects that poverty alleviation programs are the concern of the world community to be abolished. Various poverty alleviation programs have been undertaken by the government to reduce the number and percentage of the poor. But until now the phenomenon of poverty still exist. The aims of this research are 1) to analyze the difference of depth/gap of poverty level in regency/city by region of development that are in South Bali, North Bali, and East Bali; 2) To analyze the effect of economic opportunity, infrastructure availability, internal condition (positive culture), and capital accumulation on the depth/gap of poverty in Bali Province; 3) Analyze the role of capital accumulation in moderating the influence of internal conditions (positive culture) on the depth/gap of poverty in Bali Province. The study was conducted in all districts/cities with the number of respondents in each district/city as many as 30 people of the poor, bringing the total of 270 respondents throughout Bali Province. Sampling technique to be used is a combination of snow ball sampling with accidental sampling and purposive sampling. Methods of data collection used were observation, interview, and in-depth interview. Analytical techniques used are Anova and the MRA (Moderating Regression Analysis). The results of the analysis show that: 1) There are significant differences in depth/gap of poverty rate according to the development areas of South Bali, North Bali and East Bali; 2) Two variables, namely internal condition (positive culture), and the capital accumulation have negatively affect on the depth/gap of poverty, but economic opportunity and infrastructure availability have no significant effect on the depth/gap of poverty in Bali Province 3) Capital accumulation moderates (reinforces) the influence of internal conditions (positive culture) on the depth/gap of poverty in Bali Province. Taking into account the results of this analysis, then the accumulation of capital into strategic variables in reducing the level of poverty that can be intervened by the government and others.
\end{abstract}

\section{KEY WORDS}

Poverty, depth/gap, economic opportunity, capital accumulation.

Inequality of development in various regions is seen as one of the factors that can affect poverty. Thus even distribution of development in all regions is one of the conditions for reducing poverty. In Tri Logi Pembangunan, one of its parts is the equitable development of development that will generate income equity, which aims to equalize people's income. There are various factors that can affect poverty in an area, both economic factors and noneconomic factors. Economic factors are very important in the discussion of poverty given the determination of an individual or family in the category of the poor. Economically, various macro factors can influence poverty, such as economic growth, which can be reflected by how much investment is made to achieve certain economic growth. This economic growth can increase employment opportunities which are expected to increase people's income, so as to reduce the level of poverty in the area. So from economic factors, the role of economic growth becomes very important to be improved and maintained its sustainability so that employment opportunities can be created which is one of the factors that can reduce poverty. 
As stated in the 1995 World Summit for Social Development by United Nations, that unresolved affairs in the 21st century are eradicating poverty (Nehen, 2012).

The importance of reducing poverty in addition to achieving the nation's development goals of achieving a just and prosperous society based on Pancasila, reducing poverty is also very important for the achievement of the goals of the SDGs (Sustainable Development Group) which one of its goals is related to poverty. In the SDGs the first goal is alleviating poverty which is referred to as no poverty. Thus the importance of the problem of poverty alleviation is used as the first goal in the SDGs. Countries that ratify the SDGs are not only developing countries, but also in developed countries that reflect poverty problems are also still faced by developed countries so that they are used as the first destination. As Adam Smith said, 1776 is in poverty and that there is no prosperous and happy society, if most of the population is in poverty and misery (Todaro and Smith, 2006). This statement from Adam Smith shows that how important the state is to overcome the poverty of its population. The income gap is closely related to poverty. The higher income gap between high-income and low-income populations will widen the income gap between the rich and the poor. Income disparities between community groups depend on natural capabilities, human capital, and other differences, so the role of government is very important in redistributing income to achieve better equity (Mankiw, 2002).

This view shows that the role of government is very important in overcoming the gap in the distribution of people's income due to differences in resources owned by the community. The high gap in the ownership of resources in the community, the quantity and quality of capital resources or capital accumulation, the quality and quantity of human resources, and other resource gaps in society determine income inequality in society whose end results are in the form of severity and poverty. . In discussing poverty is not enough only related to the percentage of the poor, but also related to the severity of poverty which is reflected by the distance between the income of the poor and the existing poverty line. The higher the severity of poverty, the more effort must be made to alleviate poverty. Thus the analysis of poverty is not only related to the percentage of the poor that exist, but more important is the severity of poverty, or the poverty gap that occurs.

Handling the problem of poverty severity and poverty gap also reflects the level of justice in the community in handling poverty. So far, people with low poverty means that the distance of their income to the gatris limit is short of poverty, this group will be assisted first by the government so that they are faster to get out of poverty. This condition can show that the government is successful in overcoming poverty, even though justice is seen, the first thing to help is the population with more severe poverty. If those who are assisted first, the funds needed will be far more and not necessarily seen by the success of the government in alleviating poverty, and poverty alleviation programs will not be successful. Based on the concept of justice in relation to poverty alleviation, the study or discussion of the level of severity and poverty, it is very important to do to evaluate the level of justice in handling poverty problems.

Poverty can be caused due to the nature / cultural namely problems that arise in the community, and also related to the ownership of factors of production, productivity, and level of development of the community (Subandi, 2011). Furthermore, in addition to cultural factors, poverty is also caused by structural factors. In addition to the view of the causes of poverty because of cultural and structural issues, Shrap, et.al in Subandi (2011) there are 3 causes of poverty, namely: 1) Micro, poverty can arise due to inequality or inequality in the pattern of ownership of resources which ultimately affects income distribution where unequal income; 2) poverty is caused by differences in the quality of human resources; 3) poverty can arise due to differences in access to capital. Harrod-Domar's theory (Subandi, 2011) states that capital accumulation is very important in increasing economic growth, which means that increasing economic growth will increase employment opportunities which in turn can increase population income. This condition will further reduce poverty. Capital accumulation that can affect poverty, is also influenced by several factors, such as lack of trade opportunities, lack of infrastructure, disease conditions, and population growth (Sachs, 2006). Amartya Sen in C. Nunes (2002) examines the causes of poverty related to the 
paradigm of human resource development which is seen from the capabilities or capabilities possessed by HR. Poverty is said to be a function of lack of ability. Thus poverty will remain relatively constant because the speed of increasing income between one person and another is different. Team Unwin (2007) states that poverty can never be eradicated or eliminated. However, it is very important to eradicate poverty in absolute terms.

Research Objectives:

- Analyzing the difference in depth or poverty gap in districts / cities according to development areas, namely in South Bali, North Bali and East Bali;

- Analyzing the effect of economic opportunities, availability of infrastructure, internal conditions (positive culture), and capital accumulation on depth or poverty gap in Bali Province;

- Analyzing the role of capital accumulation in moderating the influence of internal conditions (positive culture) on the depth or gap of poverty in Bali Province.

Research Urgency. The depth or gap of poverty that reflects the economic condition of the poor is very important to be known and analyzed so that it can be known to those who are in a very poor condition, quite poor, less poor, or almost poor. This information is very important in order to help them overcome their poverty to be fairer, in the sense that those who should be assisted first are those who are very poor, not the near poor. The government has not categorized the level of poverty in providing assistance, for example, so that there is a possibility that those who are assisted in advance are those who are almost poor, not those who are very poor. This condition shows that there is an injustice in handling poverty alleviation that has been carried out by the government and observers of poverty. By paying attention to these conditions, then identify the depth or gap of poverty so that poverty alleviation can run more equitably. After being able to identify or classify the condition of the depth or poverty gap of the population, then the factors that can influence the depth or gap of the poverty will be examined and analyzed. By knowing the depth of poverty in each district / city, it will be possible to make policies that are fairer in helping poverty alleviation, namely which groups of people who must first be helped and which groups can later be helped so that they become more just. Likewise, knowing the area where the depth of poverty is higher, then that area must first be assisted, and more effort must be made to help the region. After knowing the factors that influence the depth of poverty, information on which factors should be given priority in the handling of the poor in order to be fairer in the effort to alleviate the poor.

Considering these conditions, this research is very important to do and contribute in order to: 1) obtain more comprehensive information to improve understanding of the conditions of the depth of poverty in Bali Province; 2) find various alternatives / ways that are more effective in reducing the depth of poverty; 3) can identify various opportunities that might be done by the government, and observers of poverty issues, to reduce the depth of poverty; 4) increase understanding of the effectiveness of various poverty alleviation programs that have been implemented by the government so far; 5 ) obtain feedback for various government policies to improve the effectiveness of these policies; 5) produce a manual for community service activities, especially for the poor to intervene in various research variables such as internal variables (positive culture) in reducing the depth of poverty.

\section{LITERATURE REVIEW}

Various definitions of poverty have been submitted by experts. A family is said to be in primary poverty if the total income cannot be used to meet the minimum needs for physical needs of the body, namely food consumption (Viet Wilson, 1986 in Sugiyarto et al, 2015). This concept emphasizes the fulfillment of physical needs to be able to live, especially food. In everyday reality someone is said to be poor if the income of the individual concerned is below the poverty line. The poverty line is different in value from one region to another, the determination of the poverty line has taken into account various things such as inflation conditions, general economic conditions of each region. Thus each region will have a certain 
poverty line of magnitude and also vary according to time. The concept of calculating the number of poor people or a certain level of poverty by comparing it to a certain poverty line is called the headcount index. In Indonesia the poverty line is determined by the Central Statistics Agency (BPS) which is the basis for classifying the population whether in the poor category or not. Absolute poverty (absolute poverty) is a number of people who are unable to obtain sufficient resources to meet their basic needs (Todaro and Smith, 2006). Nehen (2012) states that poverty here is a poor population that is a population that is unable to obtain sufficient resources to meet basic needs.

Absolute poverty is calculated by comparing certain limits of the poverty line then compared with the per capita income of the population so that it will get a headcount or head count, so that it is known how many people are below or above the poverty line. Thus, in calculating the poverty level, both percentage and absolute use the poverty line with a certain value, such as USD 2, or USD 1, or using a certain poverty line determined by the district / city whose values vary according to the conditions of the region.

Depth or poverty gap reflects how much income must be increased so that the income of the poor can reach the poverty line or they will no longer be poor. The poorer the population is, the deeper the poverty will be so that more income will be needed to get them out of poverty. Likewise, the lower the depth of poverty, the less funds or income so that they get out of the poverty level. A fairer handling of poverty will pay attention to the level of depth or poverty gap. Fairer handling is helping those who are very poor, compared to the near poor.

To calculate the number of poor people in absolute terms as well as the percentage, only a certain poverty line is needed. However, the number and percentage have not reflected a more comprehensive and in-depth condition regarding the condition of poverty. The number of poor people and the same percentage has not shown that the conditions of poverty in the two regions are the same. This same condition still requires a more in-depth analysis of poverty or the depth of poverty and the severity of poverty. The gap or depth of poverty is determined by how far the average income of the poor is in one area with the existing poverty line. The distance between the average income of the poor and the poverty line is called the gap / depth of poverty. The farther the distance between the average income of the respondent and the poverty line, the deeper the gap / depth of poverty, and vice versa. So it can be calculated from all these poor individuals how much additional income is needed so that all poor individuals have income equal to the poverty line (Nazara, 1997). Thus between one poor individual with another poor individual will require different income additions to be able to achieve income equal to the poverty line. The more additional income needed means that poverty is getting deeper / deeper into poverty, and vice versa. So the gap of poverty is nothing but the total amount of total income needed so that all poor individuals have income equal to the poverty line.

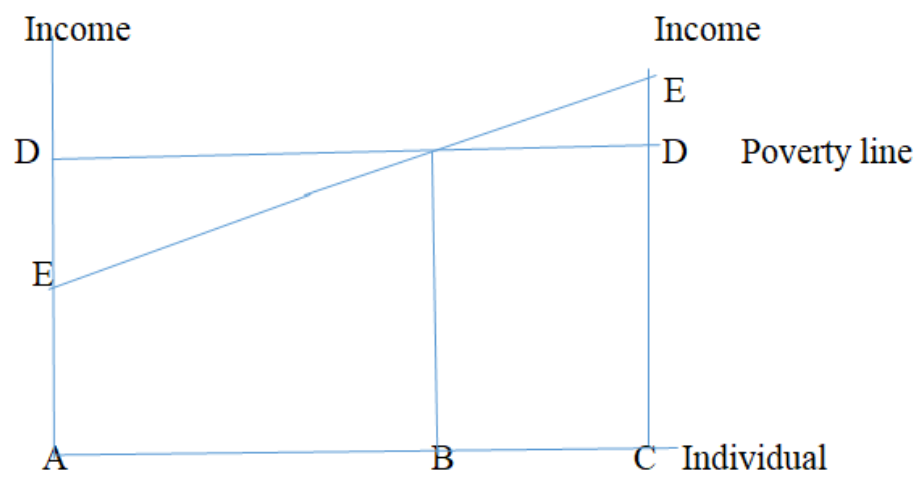

Figure 1 - Poverty Depth

Figure 1 shows the poverty gap or depth that is illustrated by the distance of points $D$ and $E$. The EE line shows population income and the DD line is the poverty line. The highest 
gap / depth of poverty is in the population that earns income at point $\mathrm{E}$, which has the widest distance with point $D$. The population classified as poor is the population from $A$ to $B$, while above $B$ to $C$ are classified as non-poor. The more right from $A$ to $B$ the lower the depth of poverty. In poverty alleviation programs that are more equitable to be helped out of poverty are those who are in income E. However, in general, the amount of funds for poverty alleviation is limited, so that the success of poverty alleviation is higher, there is a tendency for those who have a shorter poverty gap to be alleviated / assisted first. This condition certainly looks unfair, because those who should be assisted first are the poorest. This is what drives the depth and severity of poverty to be considered in poverty alleviation programs to be fairer.

\section{METHODS OF RESEARCH}

The research carried out in all districts/cities in Bali Province by considering areas that have pockets of poverty in an effort to find research respondents. Until now the data shows that in all districts / cities there are still a large number of poor people whose numbers and percentages have not moved much from previous years.

There are 2 types of data used in this study, namely quantitative data and qualitative data. There are several characteristic differences between the two types of data. Sekaran, (2010) states that quantitative data is data that has a certain unit of calculation and can be applied to mathematical operations such as added, subtracted, divided, or multiplied. In this study can be mentioned some examples of quantitative data used include depth or poverty gap, age of respondents and family members, number of years of respondent and family success, number of family members, capital accumulation, demographic conditions, and household income. Qualitative data is data that is not numeric and does not have a specific unit of calculation. In this study there are quite a number of research variables in the form of qualitative data such as internal variables (positive culture), availability of infrastructure seen from access by the poor population to various types of existing infrastructure, economic opportunities, condition of the walls of the house, type of bathing water, washing, latrines and so on.

This study uses 2 data sources namely primary and secondary data sources. The source of primary data is mainly obtained from research respondents, namely residents who are classified as poor, and informants, including officers from the agency who handle poverty alleviation issues, some of the poor people. The primary data in this study is used as the main data to answer the research objectives. Supporting data is also needed in this paper, which can come from secondary data from BPS and other sources. Examples of secondary data that are used for example are the distribution of the poor both in absolute and relative terms, as well as by different districts / cities and at different times.

Sugiono (2000), states that the population is the region of generalization from which the sample will be taken. Every research that uses primary data to answer the research objectives will identify the research population. The research population will depend on the research objectives that the researcher wants to answer. Thus the population in this study is the entire population whose income is below the poverty line, or it can be said that the population is classified as poor. The number of poor respondents who will be examined in each district / city is determined by quota as many as 30 people in each district / city so that the total respondents become 270 people. The selection of a sample of 30 people in each district / city uses the consideration of samples that have been classified as statistically large samples to be applied to parametric statistics of 30 people. There are 2 sampling techniques in general, namely probability sampling and non-probability sampling and accidental sampling and snowball sampling including non-probability sampling (Silalahi, 2009). In this research the sampling technique that was first used was accidental sampling, namely who was met first by the researcher and he was the population of this study then an interview would be conducted. Furthermore, based on the respondent's instructions, the next respondent will continue to search, and so on until the desired number of respondents is 
obtained. So after accidental sampling technique will be continued with snowball sampling technique until the number of samples is obtained according to the desired amount.

Some methods or methods of data collection that can be used by researchers to collect data on social research include observation, interviews, experiments, and survey techniques (Jogiyanto, 2004). In this study there are several data collection techniques that can be used, among others, the first is observation, which has been used by researchers when preparing research proposals. After the observation method, the data collection techniques used are interviews and in-depth interviews.

In assessing the conditions of depth of poverty or poverty, the statistical analysis technique used is statistics. Average (mean), median, mode, decile, percentile, maximum or minimum value that can be used for descriptive statistics. In addition to seeing or assessing the depth of poverty. After analyzing descriptively, then inferential analysis is carried out to answer the research objectives.

Data analysis techniques that will be used to answer the research objectives in this study adapted to the research objectives to be achieved. In accordance with the objectives of the data analysis technique research that will be used is inferential statistics namely regression with moderation that has an associative level of explanation. Regression with moderating variables is a data analysis technique which is an extension of regression analysis by adding one variable namely the moderating variable in the analysis model used or what is called the MRA (Moderating Regression Analysis). The moderating variable is the capital accumulation variable.

\section{RESULTS AND DISCUSSION}

Respondent education in this study was also shown to see trends between education and income of respondents. The following is the distribution table of respondents according to education. Data in Figure 2 shows that the education level of respondents is mostly at the elementary level and below, which is about 76 percent of the total respondents, and the remaining around 24 percent has secondary school education especially junior and senior high school, where only about 10 percent have a high school education. When viewed on average by looking at the number and percentage of respondents in each age group, it can be said that the average education of respondents is at the level of primary school education. With such an average education, it can be said that the productivity of respondents tends to be low. Low productivity will be followed by low income.

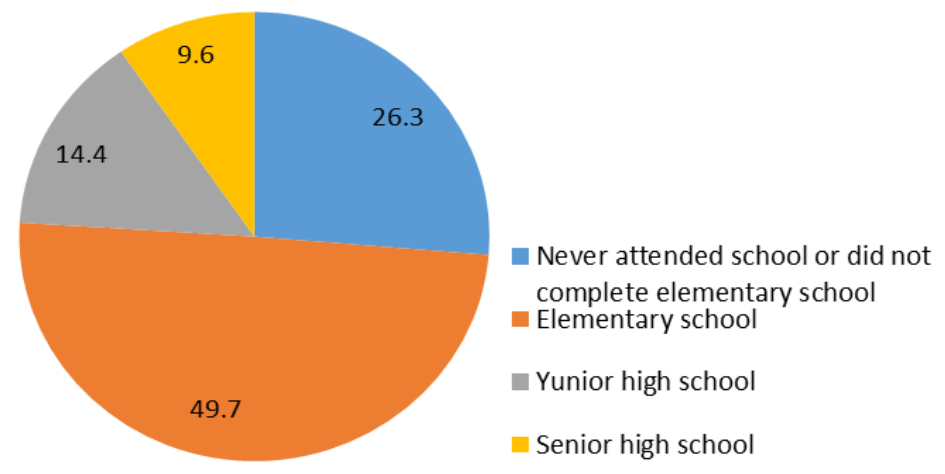

Figure 2 - Distribution of Respondents by Education

Data from the results of this study indicate that most respondents are men, which is about 70 percent and the remaining 30 percent are women. The greater number of male respondents related to the status of the head of the family, which is generally male, and the respondents in this study were the majority of family heads. Judging from the marital status, only 6 percent are unmarried (one of the family members) and the rest are married and widowed/divorced. So there are quite a lot of respondents who are family heads who are widows or widowers who are elderly and live alone or live alone without other families. 
Differences in the level of depth of poverty according to development areas. The depth of poverty between development regions can show how the intensity and success of development are carried out in all fields in the region concerned. In the Province of Bali the development area is often divided into 3 regions, namely North Bali (Buleleng and Jembrana Regencies), South Bali (Tabanan, Badung, Denpasar, and Gianyar) and East Bali (Bangli, Klungkung, and Karangasem). Differences in the intensity of development in all fields can affect the differences in income received, thus affecting the depth of poverty that occurs.

Table 1 - Average Level of Poverty Depth, Minimum, Maximum in the Development Area of Bali Province

\begin{tabular}{|c|c|c|c|c|}
\hline No & Development Area & Average & Minimum & Maximum \\
\hline 1 & South Bali & 24,95 & 1,82 & 161,65 \\
\hline 2 & East Bali & 34,15 & 0,95 & 188,44 \\
\hline 3 & North Bali & 63,01 & 4,38 & 250,90 \\
\hline 4 & Total & 36,48 & 0,95 & 250,90 \\
\hline
\end{tabular}

Source: Primary Data Processing Results, 2018.

The results of the analysis in this study indicate that there are differences both in the data on the average level of poverty depth and the data on the lowest level of poverty and the highest among the regions of development. The average depth of poverty in the North Bali Development Area is 63.01 percent which indicates that on average the income of the poor must be increased by 63.01 percent from their original income to reach the poverty line in their respective regions. This also means that to be above the poverty line, income must be increased by more than 63.01 percent for the poor population in the North Bali development area. In the East Bali Region, the average depth of poverty reached 34.15 percent, which means that on average around 34.15 percent of the income of the poor must be increased from their original income to reach the poverty line. To be above the poverty line, their income must rise above 34.15 percent. For the South Bali Development Area, the average poverty level reaches 24.95 percent, which means that the average income of the poor must be increased above 24.95 percent to reach income above the poverty line. In total, the average depth of poverty in Bali Province reached 36.48 percent, which means that the average income of the poor must be raised above 36.48 percent of their original income so that no more people are classified as poor. The following is a test of the average difference in the level of poverty between Bali's development regions.

Table 2 - Results of Different Mean Test of Poverty Depth Levels among Development Area in the Province of Bali

\begin{tabular}{|c|c|c|c|c|}
\hline No & \multicolumn{3}{|c|}{ Development Area } \\
\hline 1 & North Bali & East Bali & South Bali & Significance of Different Tests \\
\hline 2 & 63,01 & 34,15 & - & 0,001 \\
\hline 3 & 63,01 & - & 24,95 & 0,000 \\
\hline 4 & - & 34,15 & 24,95 & 0,006 \\
\hline
\end{tabular}

Source: Primary Data Processing Results, 2018.

The data in Table 2 shows that there are differences in the level of poverty between development regions in the Province of Bali. The highest average depth of poverty is found in North Bali, and the lowest is in South Bali. If tested statistically with an average difference test it turns out that all the differences are significant not only at the 5 percent significance level, also significant at the 1 percent significance level. The greatest level of difference exists between North Bali and South Bali, not only can be seen in absolute terms, but also seen from the level of significance of 0,000 . The smallest difference is between the regions of East Bali and South Bali, however, the three development regions have a significantly different average depth of poverty. This condition shows there are differences from various sides between the three development regions, where development in the South Bali Region which is often also called the Sarbagita Region can be said to be the most successful by 
looking at the average lowest poverty depth. This condition is strongly supported by investments in various fields, especially in the tourism industry as the leading development sector in Bali Province. This condition affects the level of economic growth and higher per capita income compared to other development areas. Likewise, the percentage of poor people in the Sarbagita Region (South Bali Development Area) is lower than in other regions. The 2016 data shows that the average poverty rate in the Sarbagita Region is around 3.4 percent, while the other areas are much higher (BPS, 2017).

Economic growth reduces poverty through two ways, namely creating employment opportunities and increasing wages (C. Nunes, 2002). Public expenditures today are a very important instrument which act in the economic, political and social development of a country (Çakerri et all, 2014). The opposite of economic growth, namely the economic crisis will have an impact on increasing the poor population (Suryahadi and Sumarso, 2003). Although tourism development is in the entire province of Bali, it is mostly found in the South Bali Development Area. By looking at this condition, the equal distribution of investment in all fields of development should be directed more to the North Bali Development Area to reduce the depth of poverty. Inclusive economic growth which is expected to reduce poverty, but on the contrary economic growth caused by increased non-investment consumption will be difficult to reduce poverty as the results of research by Zuhdiyaty (2017) which states that the level of economic growth that is not qualified cannot reduce poverty.

Influence of economic opportunities, availability of infrastructure, positive culture, and accumulation of capital to depth / poverty gap in Bali Province. The discussion of poverty is not only related to the number or percentage of poor people in an area, but what is more important and fairer is the depth or gap of poverty that occurs. Depth or poverty gap reflects the distance between the income of the poor and the poverty line in each region. In this study the dependent variable used is the depth of poverty which is thought to be closely related to economic opportunities. In this study also used capital accumulation as a variable that moderates the influence of economic opportunities, infrastructure availability, and internal conditions (positive culture) to depth or poverty gap in Bali Province. With this model can be made structural equation and figure as follows:

$$
Y=b_{0}+b_{1} X_{1}+b_{2} X_{2}+b_{3} X_{3}+b_{4} X_{4}+b_{5} X_{4} X_{3}+E
$$

Based on the results of the data analysis, the equation can be conveyed as follows:

$$
Y=40,287-7,031 X_{1}+2,473 X_{2}-7,434 X_{3}-0,055 X_{4}+0,018 X_{4} X_{3}
$$

Where: $Y=$ depth or poverty gap; $X 1=$ economic opportunity; $X 2=$ infrastructure availability; $\mathrm{X} 3=$ internal conditions (positive culture); $\mathrm{X} 4$ = capital accumulation; $\mathrm{X} 4 . \mathrm{X} 3=$ moderation of capital accumulation with a positive culture.

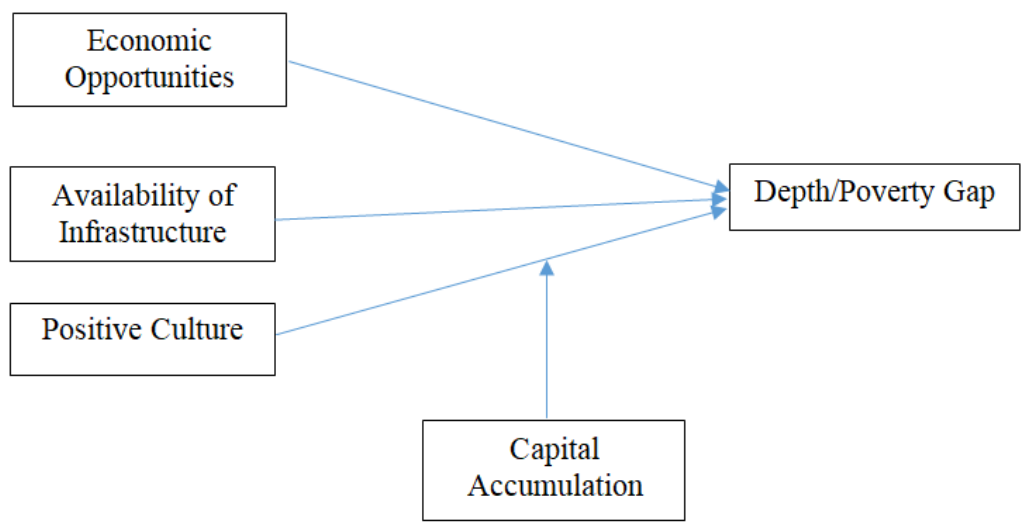

Figure 3 - The role of capital accumulation in moderating the influence positive culture on the depth or gap of poverty in Bali Province, Indonesia 
Economic opportunity variable $\left(\mathrm{X}_{1}\right)$ has a negative influence on the level of depth or poverty gap with a probability or significance of 0.582 . These results indicate that economic opportunity variables have a negative effect, but not significant. This negative influence gives a general meaning that the higher the economic opportunities they have, the lower the depth or gap of poverty they have. In this study this negative sign shows respondents who have economic opportunities; the poverty depth is lower than the respondents who do not have economic opportunities, although statistically insignificant. O'Connor (2000) states that economic inequality is the cause of poverty, so economic inequality must be reduced. Reform in the economic field is also one way to reduce poverty (Siggel, 2010). Annim et al. (2012) in Sugiyarto et al. (2015) viewed the relationship between inequality and poverty as a pragmatic relationship, namely that the gap causes poverty to worsen or the gap is a form of poverty.

Infrastructure availability variable (X2) in this study does not have a negative effect on the level of depth or poverty gap. This condition shows that the availability of infrastructure in this study does not affect the level of depth or existing poverty gap. This condition also shows that there are other variables that are more instrumental in determining the depth of poverty. In general, the availability of infrastructure in Bali Province is in adequate condition, so that the optimization of the role of infrastructure availability is related to other variables being very important. Sarma (2007) states that if they are very poor, then they will not be able to get out of poverty, if not so poor there may be little income saved. In the poor, all income is used to meet the needs of life. This is the main problem for the poor.

Internal conditions/positive cultural variable (X3) has a negative effect on depth or poverty gap. The probability or significance of this variable in influencing the depth of poverty or poverty gap is 0.039 . This means that there is a significant negative influence of internal / positive condition variables on the depth or poverty gap or this positive internal / cultural condition variable has a significant negative effect on the level of 3.9 percent. This condition also means that the higher the positive cultural conditions, the lower the level of depth / poverty gap that occurs. Someone is classified as culturally poor if the person has an attitude of not wanting to try to improve his living conditions, even though there is an effort from another party to help him, that person feels not poor (Windia, 2015).

Capital accumulation variable (X4) also has negatively affects on the level of depth or poverty gap. The higher the accumulation of capital owned by the poor, the lower the level of depth or poverty that occurs. The probability or significance of this variable is 0.079 . If a significance level of 10 percent is used, this capital accumulation variable has a significant negative effect on the depth of poverty or poverty gap. Strictly speaking it can be said that capital accumulation affects the depth or gap of poverty at a significance level of 7.9 percent. Thus it can be concluded that capital accumulation is one of the independent variables which also has a significant influence on the depth / gap of poverty in the Province of Bali. This result is consistent with research conducted by Sachs, 2006 that causes poverty is the accumulation of capital that is not owned by the poor.

The role of capital accumulation in moderating the influence of internal conditions (positive culture) on the depth or gap of poverty in Bali Province. In Economic Growth Theory, the accumulation of capital becomes very important in spurring economic growth in an area (Harrod-Domar, 1946 in Mulyadi S, 2014). Economic growth is an important variable in reducing the unemployment rate which has implications for increasing people's income which can also directly affect the depth or gap of poverty that occurs in the community. Seeing the importance of the role of capital accumulation in increasing population income, in this study is used as a moderating variable that can strengthen the influence of internal conditions (positive culture) on the level of depth or poverty gap. The results of data analysis show that the variable capital accumulation in moderating the influence of internal conditions (positive culture) on the level of depth or poverty gap has a positive sign with a value of 0.018 . The meaning of this positive value is that capital accumulation strengthens the influence of internal conditions (positive culture) on the depth or gap of existing poverty. Thus it can be concluded that capital accumulation is a moderating variable that strengthens the influence of internal conditions (positive culture) on the depth/gap of poverty in Bali Province. 
This condition can be interpreted as capital accumulation owned by the poor can increase motivation to get out from their poverty conditions.

\section{CONCLUSION}

Some conclusions that can be drawn from the results of data analysis and discussions that have been carried out previously are presented as follows.

There is a significant difference in the level of depth / poverty gap between development areas in Bali Province, namely North Bali with an average poverty depth of 63.01 percent, East Bali around 34.15 percent and South Bali with an average depth / poverty gap at the lowest of 24.95 percent. This data shows a significant difference in the average depth / poverty gap between development regions in Bali Province.

Variables of economic opportunities and infrastructure availability have no significant effect on the level of depth / poverty gap, while internal conditions (positive culture) and capital accumulation have a significant negative effect on the level of depth / poverty gap in Bali Province.

Capital accumulation moderates or strengthens the influence of internal conditions (positive culture) on the level of depth/poverty gap in Bali Province. This means that capital accumulation strengthens negative influences of internal conditions (positive culture) to the depth /gap of poverty in Bali Province.

\section{SUGGESTIONS}

Based on the results of the analysis that has been carried out and the conclusions that have been submitted, the following suggestions can be submitted.

Accumulation of capital becomes very important both as a dependent variable and a moderating variable, thus increasing capital accumulation such as assistance for business capital, as well as assistance to improve the quality of human resources as other forms of capital.

Internal conditions (positive culture) that have a significant negative effect on the level of depth /poverty gap, so the increase in motivation and enthusiasm of the community to come out and increase confidence to be able to get out of their conditions through various socialization and other activities is very important to do both by the government and people who have commitment on the problem of poverty conditions.

\section{REFERENCES}

1. Badan Pusat Statistik. 2017. Bali Dalam Angka. 2017. Denpasar: Badan Pusat Statistik Bali

2. Çakerri, Lorena; Migena Petanaj; Oltiana Muharremi. 2014. The effect of government expenditures on economic growth. The case of Albania. European Journal of Social Sciences Education and Research. Vol.2, No.1, p.242-254.

3. C. Nunes, 2002. The Evolution of the Economic Thought on Poverty Measurement. Madeira University DGE - Universidade da Madeira Caminho da Penteada. Portugal.

4. Jogiyanto. 2004. Metodologi Penelitian Bisnis. Yogyakarta : BPFE Yogyakarta.

5. Mankiw, N.Gregory. 2002. Principles of Economics, Pengantar Ekonomi Mikro. Jakarta: Penerbit Salemba Empat.

6. Mulyadi, S. 2014. Ekonomi Sumber Daya Manusia Dalam Perspektif Pembangunan, Edisi Revisi. Jakarta: PT Raja Grafindo Perkasa.

7. Nehen, I Ketut. 2012. Perekonomian Indonesia. Denpasar: Udayana University Press.

8. O'Connor, Alice. 2000. Proverty Research and Policy for the post welfare era, Annu. Rev. Sociol..26: 547-562, copyright, c. 2000, by annual review.

9. Silalahi, Ulber. 2009. Metode Penelitian Sosial. Bandung: PT Refika Aditama.

10. Sugiyono. 2000. Metode Penelitian Bisnis. Bandung: CV Alfa Beta. 
11. Sekaran, Uma. 2000. Research Method For Business. United Kingdom: A John Wiley and Sons.

12. Subandi. 2011. EkonomiPembangunan. Bandung: CV Alfabetha.

13. Sachs, J.D. 2006: Book Review:, The end of poverty: How we can make it happen in our life.Economics of Transitions, Volume 14 (3): pp: 575-577.

14. Siggel, E. 2010. Poverty alleviation and economic reforms in India. Progress in Development Studies Vol.10, Number 3, pp. 247-59.

15. Sarma, Salendra. 2007. Book Review The End of Poverty. Callange. Vol 50 No.2, hal 5966.

16. Suryahadi, A, and Sudarno Sumarso, 2003. Evolution of Poverty During the crisis in Indonesia. Asean Economic Journal, Vol 17, No3, hal 221-241.

17. Sugiyarto; J. H, Mulyo; R N Seleky. 2015. Poverty and Income Inequality among Households in Bojonegoro Regency. Agro Ekonomi .Vol. 26/No. 2, hal.115-120.

18. Tim Unwin. 2007. No End to Poverty.Journal of Development Studies, Vol. 43, No. 5, 929-953.

19. Todaro, M. and Stephen C Smith. 2006. Pembangunan Ekonomi, Edisi Kesembilan, Jllid 1. Jakarta: Penerbit Erlangga.

20. Windia, Wayan. 2015. Sekali Lagi Tentang Kemiskinan di Bali. Piramida: Jurnal Kependudukan and Pengenbangan SDM. Volume IX, Nomor 1, Halaman 1-7.

21. Zuhdiyaty, Noor. 2017. Analisis Faktor - Faktor Yang Mempengaruhi Kemiskinan Di Indonesia Selama Lima Tahun Terakhir (Studi Kasus Pada 33 Provinsi). JIBEKA. Volume 11 Nomor 2 Halaman: 27 - 31. 